This item was submitted to Loughborough's Research Repository by the author.

Items in Figshare are protected by copyright, with all rights reserved, unless otherwise indicated.

\title{
Homeostasis in Shakespeare
}

PLEASE CITE THE PUBLISHED VERSION

VERSION

NA (Not Applicable or Unknown)

LICENCE

CC BY-NC-ND 4.0

REPOSITORY RECORD

Egan, Gabriel. 2019. "Homeostasis in Shakespeare”. figshare. https://hdl.handle.net/2134/6016. 
This item was submitted to Loughborough's Institutional Repository (https://dspace.lboro.ac.uk/) by the author and is made available under the following Creative Commons Licence conditions.

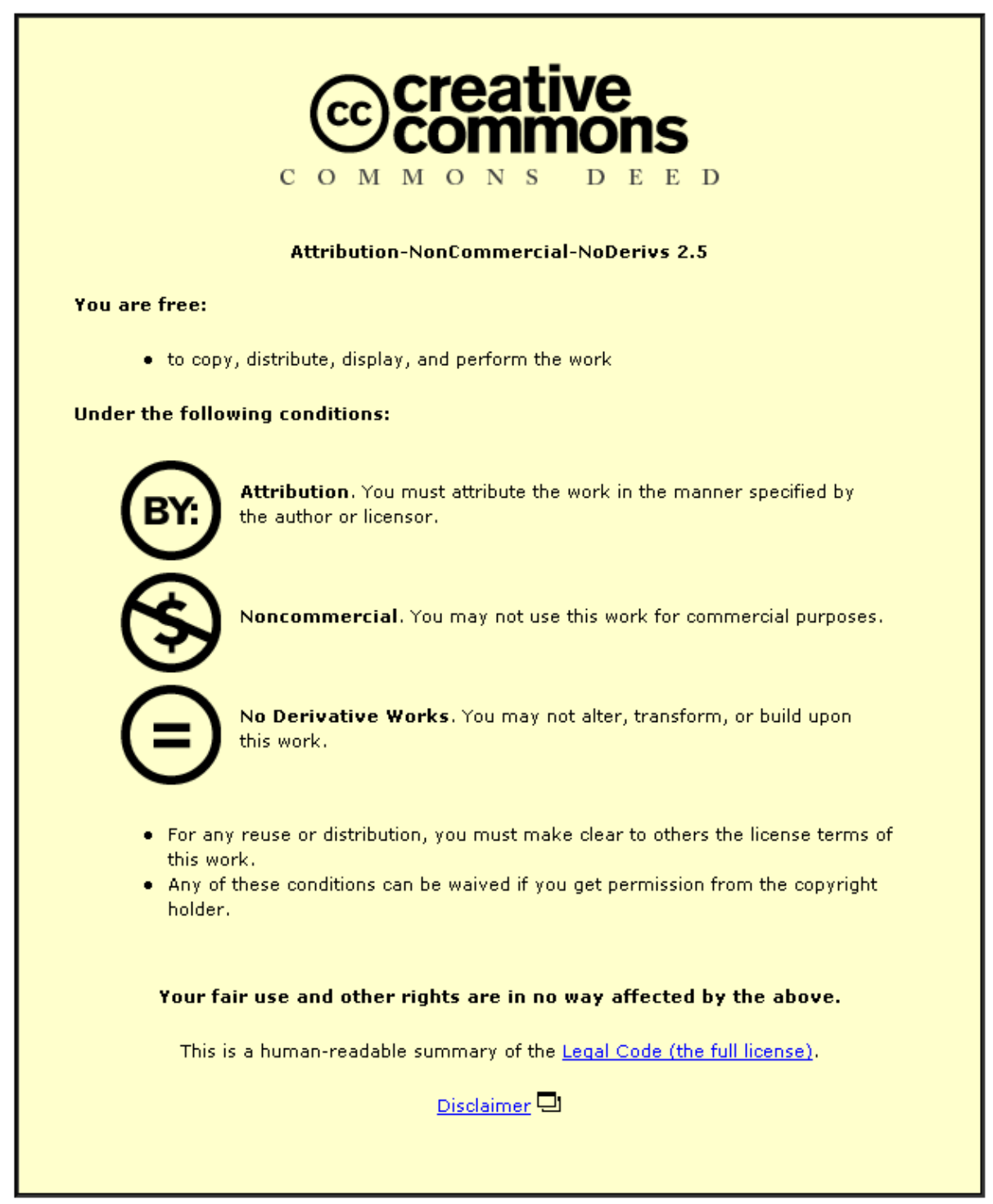

For the full text of this licence, please go to: http://creativecommons.org/licenses/by-nc-nd/2.5/ 


\section{"Homeostasis in Shakespeare" by Gabriel Egan}

[OPENING SLIDE (BLUE MARBLE)] Rene Descartes was wrong, and Shakespeare could have told him so. Descartes's hard distinction between the inanimate and the merely living machine-matter on one hand, and the mind made of an immaterial essence on the other, no longer convinces anyone. Since Charles Darwin we have accepted not a hard distinction but a continuous spectrum (indeed, a chain) of complexity and sensitivity connecting the low-order lifeforms and the higher, and recently it has become apparent that high-order rationality too is just a sophistication of simpler kinds of biological responsiveness. As Antonio Damasio has shown, the apparatus for thinking is built upon the simpler messaging systems common to animals and plants and that, essentially, we think with our bodies and not with disembodied minds (Damasio 1995). It's not surprising that with this closing of the gap between humans and all other life (lower forms around us now, and the lower forms we evolved from), scientists are increasingly finding evidence that the behaviours we call culture, morality, and politics occur in communities of animals (De Waal 1982; De Waal 2001; Whiten, Horner \& De Waal 2005).

James Lovelock's Gaia hypothesis extends this chain of being up to the planetary scale and down to the mere matter comprising the land, sea, and air. In its strongest form, Gaia sees the whole Earth as a living organism, one that might even (in Daniel Dennett's deliberately provocative phrase) have finally grown a nervous system: us (Dennett 2003b). In its weakest form, which shades off into Earth Systems Science, the Gaia hypothesis treats the Earth's chemical and thermodynamic processes not as life itself but as a collection of tightly coupled feedback loops producing planetary homeostasis, or self-regulation. We see homeostasis all around us, but it can be hard to recognise and explain. [SLIDE] For instance, the moon takes exactly as long to turn once on its axis as it does to orbit once around the Earth, which is why it always presents the same face to us. In the geocentric model of the universe this had been explained by the moon being fixed to a crystal sphere encompassing the Earth and turning with it as the sphere rotated. But once Copernicus and Galileo had worked out the correct locations and motions of the heavenly bodies and Isaac Newton and Johannes Kepler had derived the forces governing them, the moon turning at just the right rate to keep its face to us looked like a celestial miracle of coincidence. It was almost the twentieth century before George Howard Darwin, Charles Darwin's son, figured out how the laws of gravity made the Earth-moon system self-regulating (Darwin 1898). If we managed to perturb the moon, giving it an extra spin in order to see around the other side, it would react by turning back to show its familiar face to us, and solely because of gravitational forces. [BLANK SLIDE]

Earth Systems Science is finding self-regulation in places nobody suspected before, thereby reactivating pre-Enlightenment views on matter, the universe and life. Shakespeare's characters debate self-regulation and find it at work in things we consider to be alive and in things that, until recently, we did not. The Earth shook at Owen Glendŵr's birth, of that the protagonists agree. But why did it shake? Owen Glendŵr says it was out of fear [SLIDE]:

GLYNDŴR

The front of heaven was full of fiery shapes, 
Of burning cressets; and at my birth

The frame and huge foundation of the earth

Shaked like a coward.

(1 Henry 4 3.1.13-16)

Hotspur accepts the shaking but not the cause: "I say the earth was not of my mind | If you suppose as fearing you it shook" (3.1.20-22). At best, the Earth but belched or farted at Glendŵr's birth [SLIDE]:

\section{HOTSPUR}

Diseased nature oftentimes breaks forth

In strange eruptions; oft the teeming earth

Is with a kind of colic pinched and vexed

By the imprisoning of unruly wind

Within her womb, which for enlargement striving

Shakes the old beldam earth, and topples down

Steeples and moss-grown towers. At your birth

Our grandam earth, having this distemp'rature,

In passion shook.

(1 Henry 4 3.1.25-33)

As Edmond Malone pointed out (Shakespeare 1821, 3.1.33n3), the same image of winds trapped in the Earth occurs in Edmund Spenser's The Faerie Queene (3.9.15.2-9) and in Shakespeare's poem Venus and Adonis: "As when the wind, imprisoned in the ground, | Struggling for passage, earth's foundation shakes" (Venus and Adonis 10467). But in Spenser's poem and in Venus and Adonis the wind has agency--has a desire for release--and the Earth is merely its prison, a foundation to be shaken. Hotspur, on the other hand, sees the Earth as the agent here: the Earth breaks wind to correct itself by relieving the build-up of internal pressure.

These ideas have been an embarrassment to criticism. Shakespeare seems to share his characters' belief in a vital and alive universe rather than a mechanical one. We can tell Shakespeare's view because Hotspur is pricking Glendŵr's pomposity, yet he does not challenge the idea that the Earth responded as a living creature. Hotspur merely substitutes flatulence for fear as the cause of this response. As late as 1765, Samuel Johnson was able to read Hotspur's explanation as "a very rational and philosophical confutation of superstitious errour" (Shakespeare 1765, 3.1.28n6), meaning that Glendŵr is superstitious and Hotspur's explanation is rational. In the notes to his 1768 edition Edward Capell wrote that as an explanation of earthquakes "the Poet's physics are certainly right", albeit "the dress he has put them in . . . is suited to the mouth they proceed from" (Capell \& Collins 1779-80, 159). I do not suppose Johnson and Capell meant that they accepted Hotspur's image as literally true: I imagine they saw it, much as we would until recently, as a metaphor that comes closer to the truth than Glendwir's idea of a fully conscious world capable of fearing his nativity. [SLIDE]

Until recently, most scientists would have said that howsoever metaphorical Hotspur's explanation is unhelpful since there is nothing remotely biological at work in earth tremors. Indeed, the Gaia hypothesis was at first resisted by Earth Systems scientists precisely because it seemed biological. The Gaia hypothesis now incorporates plate tectonics and earthquakes, and hence encompasses the phenomena Hotspur tries to explain (Worsley, Nance \& Moody 1991; Berner 1991). Earthly exhalation is also where 
Gaia started, for the atmospheric disequilibrium it set out to explain is the rich concentrations of oxygen and methane that could not co-exist for long were not living creatures replenishing them by respiration and farting/belching. Hotspur was right: the living Earth belches and dead planets do not. It might be objected here that atmospheric methane comes from individual organisms' digestive processes not the whole Earth's. Gaia shows that this distinction between part and whole is false: the living Earth is its collection of parts, as is the organism. The average human has about 10 times as many microorganisms--separate creatures with their own DNA and reproduction cycle--living in her digestive tract as she has cells in her body, and it's these that make her farts and her belches as they break down her food.

Zoologists used to object that the Gaia hypothesis is anti-Darwinian, since planet-wide regulation of the atmosphere seems to imply cooperation that is at odds with natural selection's privileging of the local and the temporary advantage. Gaia, they objected, would require organisms planning ahead for their collective good, which cannot be right. Lovelock's answer invoked a principle that Darwinists only started to think carefully about since the 1960s: the environment to which an organism adapts is not a static background but includes the dynamic behaviour of other organisms, including others of its own species. Moreover, the environment can be altered by an organism. This last point is crucial, since an inheritable trait might be even more advantageous to a creature's descendants than it was to the creature that first developed it, simply because that trait changed the environment against which the adaptation's usefulness is to be measured. This means that determining whether a trait is doing an organism some good (in the evolutionary sense) may be harder to determine than it might at first seem.

In his latest work to address how natural selection might have generated planet-wide homeostasis, Lovelock explicitly puts the case in transgenerational terms regarding mutual interchange between an organism and its environment [SLIDE]:

... the first organisms must have used the raw materials of the Earth's crust, oceans, and air to make their cells. They also returned to their environment their wastes and dead bodies. As they grew abundant, this action would have changed the composition of the air, oceans, and crust into an oxygen-free world dominated chemically by methane. This means that soon after its origin, life was adapting not to the geological world of its birth, but to an environment of its own making. There was no purpose in this, but those organisms which made their environment more comfortable for life left a better world for their progeny, and those which worsened their environment spoiled the survival chances of theirs. Natural selection then tended to favor the improvers. (Lovelock 2004, 3-4).

In other words, competition between early organisms that left the area around themselves a bit easier for their progeny to live in and those that left it a bit harder for their progeny to live in would have favoured the former. The progeny of the wellbehaved had the advantage. This hypothesis does not fall foul of the fallacy of group selection, as Richard Dawkins claimed when he objected that Gaia requires the kind of selflessness that nature selection destroys because ". . . a mutant plant which saved itself the costs of oxygen manufacture ... would outreproduce its more public-spirited colleagues" (Dawkins 1982, 236). Rather, Gaian natural selection is now taken seriously by mainstream Earth Systems Science (Lenton 1998).

In the theologically-centered morality of Shakespeare's time, the ethic of reciprocity embodied in the Christian Golden Rule--'do to others as you would have them do to you' 
(Matthew 7.12)--was obviously a component of interactions within the family, or within a community, or between natives and strangers. Shakespeare repeatedly dramatized how morality emerges from such interactions, but they are not the same kind of interactions that seem to produce morality in Gaian natural selection. The Golden Rule governs social interactions within a single generation--the 'others' are those around you now-while natural selection required for Gaia occurs transgenerationally and is concerned with behaviours whose impacts upon evolutionary fitness can only be discerned over time.

However, Shakespeare does on occasion seem to address such Gaian interactions, by dramatizing selfish behaviour that seems advantageous to the individual considered synchronically, but when considered diachronically, transgenerationally, is revealed as disadvantageous. He was aware that if one's behaviour is inherited by one's children, one faces a kind of Golden Rule played out over time and hence, in crude but I think defensible terms, heredity encourages goodness. The earliest example is Lady Anne's curse on Richard Gloucester, in which she imagines him having a child as monstrous as himself: [SLIDE]

\section{[LADY ANNE]}

If ever he have child, abortive be it,

Prodigious, and untimely brought to light,

Whose ugly and unnatural aspect

May fright the hopeful mother at the view,

And that be heir to his unhappiness.

(Richard 3 1.2.21-25)

John Jowett thought that Anne's reference to deformity "glances only indirectly at" Richard's own condition (Shakespeare 2000, 1.2.21) whereas Anthony Hammond was sure that Anne is "describing Richard's own birth" and wondered whether she realizes that she is doing this (Shakespeare 1981, 1.2.23). Without speculating about the contents of Anne's mind, we can say for sure that 160 lines (about 8 minutes of stage time) earlier Richard called himself "deformed, unfinished . . half made up" (1.1.20-1), so the audience hears Anne cursing Richard with having a child like himself.

King Lear pronounces the same curse on his daughter Gonoril [SLIDE]:

\section{[LEAR] If she must teem,}

Create her child of spleen, that it may live

And be a thwart disnatured torment to her.

Let it stamp wrinkles in her brow of youth,

With cadent tears fret channels in her cheeks,

Turn all her mother's pains and benefits

To laughter and contempt, that she may feel--

That she may feel

How sharper than a serpent's tooth it is

To have a thankless child.

(History of King Lear 4.268)

Viewed as a parenting strategy, Gonoril's selfishess defeats itself and the Golden Rule is upheld, not synchronically but diachronically over the generations. 
Later Lear realizes a layer of further potential reciprocity: what if he is subject to the same curse he made upon Gonoril? That is to say, might not Gonoril herself be a deserved punishment to him just as he wishes her child to be a deserved punishment to her? [SLIDE] The sight of Edgar prompts this thought:

\section{LEAR}

What, has his daughters brought him to this pass?

(To Edgar) Couldst thou save nothing? Didst thou give them all?

FOOL Nay, he reserved a blanket, else we had been all

shamed.

LEAR (to Edgar)

Now all the plagues that in the pendulous air

Hang fated o'er men's faults fall on thy daughters!

KENT He hath no daughters, sir.

\section{LEAR}

Death, traitor! Nothing could have subdued nature

To such a lowness but his unkind daughters.

(To Edgar) Is it the fashion that discarded fathers

Should have thus little mercy on their flesh?

Judicious punishment: 'twas this flesh begot

Those pelican daughters.

(History of King Lear 11.56-68)

Lear comes to realize the errors of his ways, and in this regard we may usefully contrast him with the childless king Richard 3. Richard has hopes to start his own line of monarchs, but his imagery of generation runs precisely counter to the principle of transgenerational correction I have been outlining. Richard seems to think that by generation he will undo his crimes rather than be called to account for them: [SLIDE]

QUEEN ELIZABETH Yet thou didst kill my children.

\section{KING RICHARD}

But in your daughter's womb I bury them,

Where, in that nest of spicery, they will breed

Selves of themselves, to your recomfiture.

(Richard 3 4.4.353-6)

The childless Macbeth is much like Richard in brutally hacking his way to the throne only to find that it gives little joy without a child to pass it on to. Indeed, we may suppose that these kings are able to be brutal because they are childless: had they to face the transgenerational consequences of passing on these traits they would learn that selfishness is self-defeating.

The last plays of Shakespeare's career are especially concerned with relations between the generations. In The Winter's Tale, Paulina presents the new-born baby Perdita to Leontes and remarks on its likeness to him [SLIDE]:

PAULINA It is yours,

And might we lay th' old proverb to your charge,

So like you 'tis the worse. Behold, my lords, Although the print be little, the whole matter And copy of the father ... 
And thou good goddess Nature, which hast made it

So like to him that got it, if thou hast

The ordering of the mind too, 'mongst all colours

No yellow in 't, lest she suspect, as he does,

Her children not her husband's.

(The Winter's Tale 2.3.96-108)

Paulina means to show Leontes that he was wrong to suspect that the baby is another's child. But having asserted that the baby is like its father, Paulina must hope that Perdita is unlike her father in one quality at least: that she is not yellow (the colour of jealousy) lest she think that her children are not her own. This is of course absurd, since the uneven burden of sexual reproduction affords women one certainty: they can at least be sure that the children they give birth to are their own.

Even if heritable, Leontes's jealousy could not be transmitted down the female line, as Paulina appears to recognize as she says this. The Variorum edition of the play cites a number of critics who regard this absurdity as intentional illogic on Paulina's part, meant to show Leontes his own illogic (Shakespeare 2005, TLN 1029-30). On the other hand one might argue that this is unintentionally inflammatory: having his attention drawn to the certainty of motherhood Leontes might feel his paternal uncertainty all the more strongly. From the point of view of natural ethics--the kind of Gaian self-regulation that Shakespeare is thinking about--Paulina seems to have put her finger on a problem: transgenerational relations cannot visit Leontes's disorder upon him in the way that they can revisit Gonoril's ingratitude upon her.

An eco-critic might be expected to stress the cyclical nature of time in this play and the platitude that nature gathers in all with its recurrent return to a starting point, but I think it's at least as useful to attend to its dramatization of self-regulation (homeostasis) achieved by transgenerational correction in which bad behavioural traits inherited by offspring plague the perpetrator. Shakespeare would seem, then, not only to have anticipated the Gaian model of a vitally alive Earth, but also the role of heredity in the evolution of morality as described by Frans de Waal, Daniel Dennett, and Richard Joyce amongst others (Flack \& De Waal 2000; Dennett 2003a; De Waal 2004; Joyce 2006). Of course he anticipated neither of those things; rather, unencumbered by the sharp distinction of matter and mind that dominated Enlightenment science he (rightly, we now know) assumed that the mechanical and the organic lie along a continuous spectrum, or chain of being.

\section{Works Cited}

Berner, Robert A. 1991. "Atmospheric Oxygen, Tectonics, and Life." Scientists on Gaia. Edited by Stephen H. Schneider and Penelope J. Boston. Cambridge MA. Massachusetts Institute of Technology Press. 161-66.

Capell, Edward and John Collins. 1779-80. Notes and Various Readings to Shakespeare. Vol. 1: All's Well That Ends Well; Antony and Cleopatra; As You Like It; The Comedy of Errors; Coriolanus; Cymbeline; Hamlet; 1 Henry IV; 2 Henry IV; Henry V; 1 Henry VI; 2 Henry VI; 3 Henry VI; Henry VIII; Julius Caesar; King John; King Lear; Love's Labour's Lost. London. Henry Hughs. 
Damasio, Antonio R. 1995. Descartes' Error: Emotion, Reason, and the Human Brain. London. Picador.

Darwin, George Howard. 1898. The Tides and Kindred Phenomena in the Solar System. London. Murray.

Dawkins, Richard. 1982. The Extended Phenotype: The Gene as the Unit of Selection. Oxford. Oxford University Press.

De Waal, Frans B. M. 1982. Chimpanzee Politics: Power and Sex Among Apes. London. Cape.

De Waal, Frans B. M. 2001. The Ape and the Sushi Master: Cultural Reflections By a Primatologist. London. Allen Lane.

De Waal, Frans B. M. 2004. "Evolutionary Ethics, Aggression, and Violence: Lessons from Primate Research." Journal of Law, Medicine and Ethics 32. 18-23.

Dennett, Daniel C. 2003a. Freedom Evolves. London. Penguin.

Dennett, Daniel. 2003b. "How Has Darwin's Theory of Natural Selection Transformed Our View of Humanity's Place in the Universe?" Seventh edition. Life: The Science of Biology. 2: Evolution, Diversity, and Ecology. Edited by William K. Purves, David Sadava, Gordon H. Orians and H. Craig Heller. Sunderland MA. Sinauer. 523.

Flack, Jessica C. and Frans B. M. De Waal. 2000. "'Any Animal Whatever': Darwinian Building Blocks of Morality in Monkeys and Apes." Journal of Consciousness Studies 7. 1-29.

Joyce, Richard. 2006. The Evolution of Morality. Life and Mind: Philosophical Issues in Biology and Psychology. Cambridge MA. Massachusetts Institute of Technology Press.

Lenton, Timothy M. 1998. "Gaia and Natural Selection." doi:10.1038/28792. Nature 394. 439-47.

Lovelock, James. 2004. "Reflections on Gaia." Scientists Debate Gaia: The Next Century. Edited by Stephen H. Schneider, James R. Miller, Eileen Crist and Penelope J. Boston. Cambridge MA. Massachusetts Institute of Technology Press. 1-5.

Shakespeare, William. 1765. The Plays. Ed. Samuel Johnson. Vol. 4: The Life and Death of Richard the Second; The First Part of King Henry the Fourth; The Second Part of King Henry the Fourth; The Life of King Henry the Fifth; The First Part of King Henry the Sixth. 8 vols. London. J. and R. Tonson [etc.].

Shakespeare, William. 1821. The Plays and Poems. Ed. Edmond Malone and James Boswell. Vol. 16: Richard II; Henry IV Part I. 21 vols. London. F. C. and Rivington [etc.].

Shakespeare, William. 1981. King Richard III. Ed. Antony Hammond. The Arden Shakespeare. London. Methuen. 
Shakespeare, William. 2000. Richard III. Ed. John Jowett. The Oxford Shakespeare. Oxford. Oxford University Press.

Shakespeare, William. 2005. The Winter's Tale. Ed. Robert Kean Turner, Virginia Westling Haas, Robert A. Jones, Andrew J. Sabol, Patricia E. Tatspaugh. The New Variorum Edition of Shakespeare. New York. The Modern Language Association of America.

Whiten, Andrew, Victoria Horner and Frans B. M. De Waal. 2005. "Conformity to Cultural Norms of Tool Use in Chimpanzees." doi:10.1038/nature04047. Nature 437. 737-40.

Worsley, Thomas R., R. Damian Nance and Judith B. Moody. 1991. "Tectonics, Carbon, Life, and Climate for the Last Three Billion Years: A Unified System." Scientists on Gaia. Edited by Stephen H. Schneider and Penelope J. Boston. Cambridge MA. Massachusetts Institute of Technology Press. 200-10. 